\title{
An operational method for estimating cold tolerance thresholds of white spruce seedlings in forest nurseries
}

\author{
by Sylvie Carles ${ }^{1,2}$, Mohammed S. Lamhamedi ${ }^{3}$, Debra C. Stowe ${ }^{1}$, Linda Veilleux ${ }^{3}$ and Hank A. Margolis ${ }^{1}$
}

\begin{abstract}
Cold damage leads to the rejection of millions of seedlings each year in northern forest nurseries. Nursery managers need a procedure to estimate the degree of hardening at a specific time in order to make decisions to avoid seedling loss. Estimates based on variables that are quick and easy to measure such as thermal time, a variable quantifying the cumulative effect over time of temperatures below a given threshold, and apical dry mass ratio (DM/FM) hold particular promise. In this study, two-year-old white spruce containerized seedlings were subjected to artificial freezing tests. The progression of $\mathrm{DM} / \mathrm{FM}$ during the fall was determined and the thermal time was quantified by calculating hardening degree days (HDD) based on air temperature and a specific threshold for white spruce. Results establish that cold tolerance thresholds are associated with easily identifiable specific DM/FM and HDD values for nursery $\times$ species $\times$ seed source combinations.
\end{abstract}

Key words: Picea glauca, cold damage, hardening, apical dry mass ratio, hardening degree days

\section{RÉSUMÉ}

Les dommages causés par le gel sont à lorigine du rejet annuel de millions de semis dans les pépinières forestières nordiques. Les pépiniéristes ont besoin d'une procédure pour estimer le degré d’endurcissement à un moment précis pour prendre des décisions qui permettront déviter la perte de semis. Des estimations basées sur des variables facilement et rapidement mesurables, telles que le temps thermique, une variable permettant de quantifier l'effet cumulé dans le temps de températures en deçà d'une température seuil donnée, ou le ratio de matière sèche des apex (MS/MF) semblent particulièrement prometteuses. Dans cette étude, des plants dépinette blanche de deux ans, et produits en récipients, ont été soumis à des tests de gels artificiels. L'évolution du MS/MF en automne a été déterminée et le temps thermique a été quantifié en calculant des degrés jours d'endurcissement (DJE) basés sur la température de lair et une température seuil spécifique à lépinette blanche. Les résultats établissent que les seuils de tolérance au gel sont associés à des valeurs de MS/MF et de DJE facilement identifiables et spécifiques à chaque combinaison " pépinière $\times$ essence $\times$ provenance ».

Mots clés : Picea glauca, dommages causés par le gel, endurcissement, ratio de matière sèche des apex, degrés jours d'endurcissement

\section{Introduction}

Cold damage is one of the principal reasons that millions of seedlings are rejected each year in northern forest nurseries (Colombo 1997). In Québec, containerized seedlings are grown under unheated polyethylene tunnels during their first growing season. The tunnel is removed in October and a thick layer of natural snow covers the seedlings during the winter. During the second growing season and subsequent winter, the containerized seedlings are left uncovered and exposed to natural environmental conditions (Margolis 1987). Annual rejection rates due to frost damage can range from 5\% to 30\% (Lamhamedi et al. 2005). Irrigation is the most common method of protecting containerized seedlings from damage when air temperatures approach and drop below $0^{\circ} \mathrm{C}$ before the seedlings are fully hardened (Rose and Haase 1996). The formation of ice around the shoot tissue liberates heat, thus ensuring that the tissue does not freeze. Irrigation must be continued until the risk of frost has passed. This abundant application of water saturates the substrate.
Unfortunately, seedlings are unable to use the majority of this water because physiological processes slow down in the fall, thus reducing water uptake and transpiration. The surplus water, along with any dissolved solutes it contains, may leach from the growing medium into the groundwater system (Lamhamedi et al. 2001, Stowe et al. 2010). If the cold hardiness level was known, the need for irrigation during hardening could be reduced and optimized.

In most of Canada, cold hardiness of conifer seedlings is operationally determined using the freeze-induced electrolyte leakage technique (Colombo 1997, Colombo et al. 2001). This technique quantifies cell membrane damage by measuring the increase in electrical conductivity of a bathing solution after artificial freezing of plant tissue (Colombo et al. 1984). The main disadvantages of this approach are that the tests take several days to carry out and expensive equipment is required (Colombo et al. 2001). When freezing temperatures are forecast, nursery managers need to be able to estimate the level of seedling cold hardiness immediately. They

\footnotetext{
${ }^{1}$ Centre deétude de la forêt (CEF), Faculté de foresterie, de géographie et de géomatique, Pavillon Abitibi Price, Université Laval, 2405 rue de la Terrasse, Québec (Québec) G1V 0A6.

${ }^{2}$ Corresponding author. E-mail: Sylvie.Carles@RNCan-NRCan.gc.ca

${ }^{3}$ Direction de la recherche forestière, Forêt Québec, ministère des Ressources naturelles et de la Faune, 2700 rue Einstein, Québec (Québec) G1P 3W8.
} 
do not have time to conduct a freezing test, so a model that would permit the prediction of cold hardiness levels nondestructively would be very useful. Shoot cold hardening consists of two stages. The first stage is induced by a shortening of the photoperiod (Silim and Lavender 1994, Grossnickle 2000) and is concomitant with the cessation of seedling height growth. After this first stage, cold hardiness progressively increases in response to low temperatures (Grossnickle 2000, Silim and Lavender 1994). Thus, photoperiod length and temperature are relevant variables for a model estimating level of seedling cold hardiness. In Québec nurseries, white spruce (Picea glauca [Moench] Voss) bare-root seedlings are considered ready for cold storage if the chilling sum, calculated by cumulating the number of hours when temperatures are less than $5^{\circ} \mathrm{C}$, has reached a sum of 200 hours (Lambany 1994, Lamhamedi et al. 2005). According to Mullin and Parker (1976), white spruce bare-root seedlings are ready for cold storage if a minimum of 200 degree hardening days (DHD) have accumulated. In this last study, DHD were based on soil temperature and calculated by summing the degrees below a threshold value of $10^{\circ} \mathrm{C}$. The chilling sum and $\mathrm{DHD}$ provide no information on the minimum freezing temperature that the seedlings can support once they have accumulated $200 \mathrm{DHD}$ or $200 \mathrm{~h}$ at $5^{\circ} \mathrm{C}$. Before adapting the use of these variables to containerized stock, the level of frost tolerance must be known to make an informed irrigation decision when autumnal frost is forecast. Furthermore, estimation of chilling sum is based on a threshold air temperature value equal to $5^{\circ} \mathrm{C}$ (Lambany 1994). Mullin and Parker (1976) based their DHD on a threshold soil temperature value equal to $10^{\circ} \mathrm{C}$. According to Greer et al. (2001), the threshold temperature above which no cold hardiness development in white spruce occurs is $14.5^{\circ} \mathrm{C}$. Which of these three values should be used for a model that would permit prediction of seedling cold hardiness levels?

Even if the environmental variables could adequately describe the environmental cues received by the seedlings, they would not give information on the actual physiological state of the seedlings, which may also be affected by cultural practices or seed source/provenance (Colombo et al. 2001). The ratio of dry mass to fresh mass (DM/FM) of the upper $4 \mathrm{~cm}$ of the terminal shoot of conifer seedlings could be a complementary criterion linked to a seedling's physiological state. Previous studies established that the apical dry mass ratio of white spruce seedlings increases during the fall (Grossnickle 1989, Calmé et al. 1993) and under controlled growing conditions is significantly and positively correlated with cold tolerance (Calmé et al. 1993). Moreover, this relationship appears to be independent of fertilization, irrigation, photoperiod or species (Calmé et al. 1993, 1995). Calmé et al. (1993) determined that white spruce seedlings with $\mathrm{DM} / \mathrm{FM}$ of less than $30 \%$ will probably not survive temperatures below $-10^{\circ} \mathrm{C}$. This threshold value is close to the value used by Swedish nursery managers to estimate the capacity of coniferous seedlings to survive cold storage (Hultén and Lindell 1980). However, little information is available for the progression of DM/FM beyond this threshold value or for tolerance levels associated with DM/FM greater than 30\% (Calmé et al. 1993). Nursery managers are keenly interested in the lowest temperature at which no damage occurs as opposed to a temperature inferred from a threshold damage value that is lethal for the seedlings (e.g., lethal temperature, $\mathrm{LT}_{50}$ ) (Calmé et al. 1993). The use of thresholds based on these temperatures, which, by definition, will cause irreversible lethal damage, can negatively affect the profitability and sustainability of nurseries. Therefore, more information is needed to clarify the relationship between $\mathrm{DM} / \mathrm{FM}$ and the cold tolerance of white spruce seedlings hardened under natural photoperiods and temperatures in forest nurseries.

The present study of two-year-old white spruce containerized seedlings hardened under natural photoperiodic and temperature conditions in a forest nursery had the following objectives: 1) to characterize the progression of apical $\mathrm{DM} / \mathrm{FM}$ during the fall, 2) to specify the relationship between $\mathrm{DM} / \mathrm{FM}$ and cold tolerance of shoots and roots, 3) to identify environmental values that should be used to estimate levels of seedling cold hardiness that result in no damage to seedling tissue and 4) to suggest a new operational method for estimating cold tolerance thresholds of white spruce seedlings in forest nurseries.

\section{Materials and Methods \\ Seedling material}

The seedling production methodology is described in detail by Stowe et al. (2010). Briefly, seeds from a first-generation white spruce seed orchard located in Wendover arboretum $\left(45^{\circ} 59^{\prime} \mathrm{N}, 72^{\circ} 30^{\prime} \mathrm{W}\right), 80 \mathrm{~km}$ east of Montréal, Québec, Canada, were sown in IPL 25-350A air-slit containers (25 cavities per container, $350 \mathrm{~cm}^{3}$ per cavity; IPL ${ }^{\circledR}$, Saint-Damien, Qc) and seedlings were subjected to standard cultural practices during two years of growth under an unheated, polyethylene tunnel at Pampev Inc., a private forest nursery located in Saint-Louis-de-Blandford, Québec $\left(46^{\circ} 25^{\prime} \mathrm{N}, 72^{\circ} 00^{\prime} \mathrm{W}\right)$ (Margolis 1987, Stowe et al. 2010). As is customary, the tunnel was left uncovered between October 2001 and April 2002 and a thick layer of natural snow covered the seedlings during the winter. On April 30, 2002, at the beginning of the seedlings' second growing season, the tunnel cover was reinstalled so that water inputs could be controlled for a companion study (Carles et al. 2008, Stowe et al. 2010). A completely randomized block experiment, consisting of four replications (blocks), was installed along the length of one side of the tunnel. Each block contained 84 containers with a buffer zone of 28 containers between adjacent blocks.

Bud set of 300 seedlings (three containers of 25 seedlings per block) was monitored on a weekly basis, beginning on August 1,2002. Bud set was expressed as the percentage of the 25 seedlings per container which had initiated buds. The seedlings were considered to have initiated buds once the exterior scales on the terminal bud were pale yellow in color (Bigras and D'Aoust 1993). Every two weeks during the hardening period (August 1 through October 28, 2002), the dry mass ratio [dry mass/fresh mass - DM/FM (\%)] of the uppermost $4 \mathrm{~cm}$ of the terminal shoot was measured on 60 seedlings (15 seedlings/block). The 15 seedlings per block were randomly selected from three randomly selected containers in each block (five seedlings per container; three containers per block). Different containers were sampled on each date. Apical fresh mass (FM) was measured on the day of the sampling for each seedling. Apical dry mass (DM) was determined after drying the tissue for 48 hours at $60^{\circ} \mathrm{C}$. The apical dry mass ratio (DM/FM) was calculated for each seedling by dividing the apical dry mass by the apical fresh mass. 
Once all of the seedlings had formed buds (mid-September 2002), the average height, diameter and dry mass of the seedlings $(\mathrm{n}=90)$ were $33.62 \mathrm{~cm}( \pm 0.47), 6.55 \mathrm{~mm}( \pm 0.05)$ and $7.40 \mathrm{~g}( \pm 0.13)$, respectively. Foliar nutrient concentrations, determined concurrently using standardized laboratory procedures (Stowe et al. 2010), were 2.42\% ( \pm 0.02$), 0.28 \%$ $( \pm 0.002), 0.69 \%( \pm 0.004), 0.32 \%( \pm 0.002)$ and $0.19 \%( \pm 0.007)$ for nitrogen, phosphorus, potassium, calcium and magnesium, respectively. The nutrient concentrations were in the recommended range for containerized white spruce seedlings (Veilleux et al. 2012), demonstrating that the seedlings were healthy and met the morphological criteria for the growing region.

\section{Environmental conditions}

Natural photoperiod length was evaluated in hours and deduced from times of sunrise and sunset at the nursery coordinates $\left(46^{\circ} 25^{\prime} \mathrm{N}, 72^{\circ} 00^{\prime} \mathrm{W}\right)$.

Air temperature $2 \mathrm{~m}$ above ground and temperatures at the substrate surface and within the rhizosphere were continuously recorded at 15-minute intervals between July and October 2002 using a datalogger (model CR10X, Campbell Scientific (Canada) Corp., Edmonton, AB). Three individual sensors were used to measure air temperature above ground, temperature at the substrate level and temperature within the rhizosphere. The air temperature was measured by a sensor fixed to the tunnel structure at the mid-point of the tunnel length. The other two temperature sensors were placed just above the substrate level and at a depth of $5 \mathrm{~cm}$ inside a cavity in the center of a container in the middle of the seedling bed, equidistant from both sides of the tunnel and from both tunnel extremities. Air temperature dropped below freezing for the first time during the night of October 6 (minimum = $-1.1^{\circ} \mathrm{C}$ ). The lowest air temperature during the experimental period was recorded on the morning of October $15\left(-7^{\circ} \mathrm{C}\right)$. On the same morning, temperatures at the substrate surface and in the rhizosphere were $-4.6^{\circ} \mathrm{C}$ and $2.2^{\circ} \mathrm{C}$, respectively.

\section{Thermal time}

Thermal time is a way of quantifying the cumulative effect of the temperatures experienced by the seedlings. Three methods were used to estimate this variable: two that are currently used in forest nurseries (chilling sum and DHD), and a third one specific to this study (hardening degree days; HDD). Chilling sum (hours) was calculated by summing the numbers of hours when the temperature measured $2 \mathrm{~m}$ above the seedling bed was under $5^{\circ} \mathrm{C}$ (Lambany 1994). DHD were calculated following the method described by Mullin and Parker (1976). DHD were based on the minimum daily rhizosphere temperature and calculated by summing the degrees below a threshold value equal to $10^{\circ} \mathrm{C}$.

Thermal time was also quantified by the hardening degree days $\left(\mathrm{HDD}-{ }^{\circ} \mathrm{C}\right)$. HDD were based on the minimum daily temperature measured $2 \mathrm{~m}$ above the seedling bed and calculated by summing the degrees below a threshold value of $14.5^{\circ} \mathrm{C}$, which is the threshold temperature above which no cold hardiness development in white spruce occurs, according to Greer et al. (2001). For a given day, the number of accumulated HDD was equal to 0 if the minimum daily temperature was superior to $14.5^{\circ} \mathrm{C}$; otherwise it was equal to the number of degrees between $14.5^{\circ} \mathrm{C}$ and the minimum daily temperature.

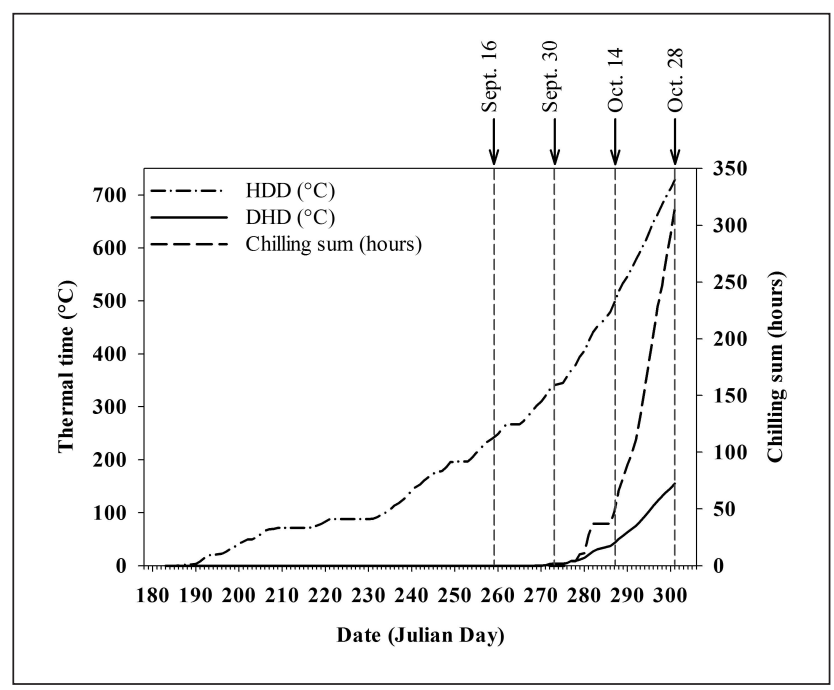

Fig. 1. Progression of thermal time $\left({ }^{\circ} \mathrm{C}\right)$ and chilling sum (hours] during the second growing season (2002) of containerized white spruce seedlings. Chilling sum was calculated in hours by summing the numbers of hours where the temperature measured 2 $\mathrm{m}$ above the seedling was less than $5^{\circ} \mathrm{C}$. Thermal time was quantified by summing the hardening degree days (HDD) and the degree hardening days (DHD). HDD were based on the daily minimum value of the temperature measured $2 \mathrm{~m}$ above the seedlings and calculated by daily summing the degrees below a threshold value equal to $14.5^{\circ} \mathrm{C}$. DHD were based on the daily minimum value of the rhizosphere temperature and calculated by summing the degrees below a threshold value equal to $10^{\circ} \mathrm{C}$. Arrows indicate the dates of artificial freezing treatments.

Accumulations of chilling sum, DHD and HDD are shown in Fig. 1.

\section{Artificial freezing treatments}

Tests were conducted during the hardening period (September and October 2002) to determine seedling cold tolerance in fall. When the first freezing treatment was applied, all seedlings had formed buds and were therefore assumed to be at the same phenological stage. These tests are described in detail in Carles et al. (2008). Briefly, using a programmable freezer and a protocol similar to that of Zhu et al. (2002), artificial freezing treatments were applied to intact seedlings (with root plugs) immediately following harvest on September 16, September 30, October 14 and October 28, 2002. Sixty seedlings per block (240 in total) were harvested on each sampling date and divided into five groups of 12 seedlings (Fig. 2.). Each group of 12 seedlings was subjected to one of five temperatures: $\mathrm{t}_{0}=+4^{\circ} \mathrm{C}, \mathrm{t}_{1}=-4^{\circ} \mathrm{C}, \mathrm{t}_{2}=-8^{\circ} \mathrm{C}, \mathrm{t}_{3}=-12^{\circ} \mathrm{C}$ and $\mathrm{t}_{4}=-20^{\circ} \mathrm{C}$. The temperature was decreased at a rate of $2^{\circ} \mathrm{C}$ /hour (Levitt 1980). Once the target air temperature around the shoot tissue was attained, it was maintained constant for one hour. To simulate nursery conditions where roots are insulated by the substrate, seedlings were removed from the containers but the root plugs were left intact around the root system throughout the freezing tests. Moreover, since saturating container substrate in the fall to prevent plant loss from root freezing is common practice in Québec forest nurseries, the containers of plants were immersed in water for two hours prior to each freezing test. Consequently, as is the case 


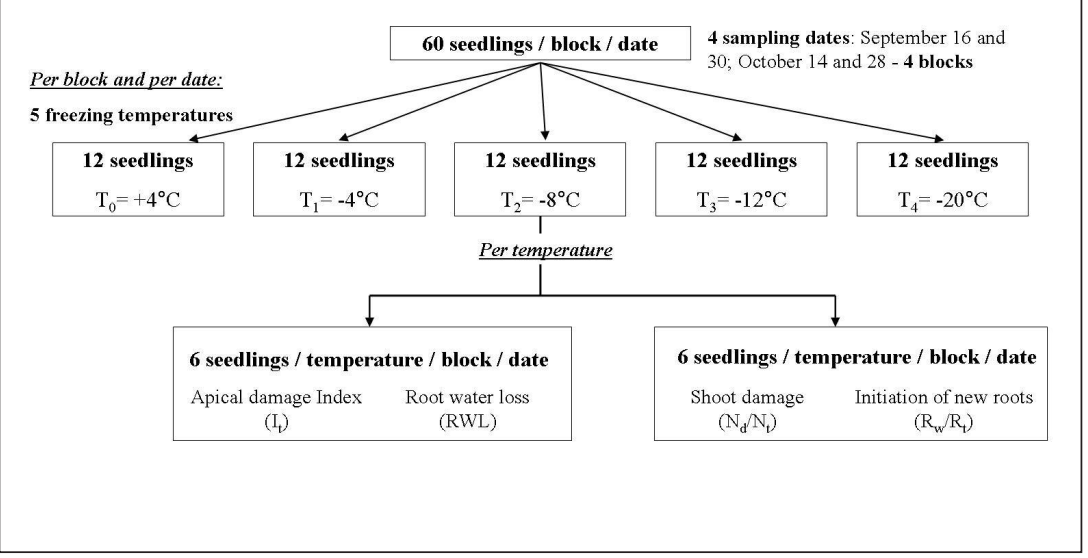

Fig. 2. Number of white spruce seedlings used to quantify root and shoot cold damage following artificial freezing treatments conducted at four sampling dates.

in natural conditions, rhizosphere temperatures were always several degrees higher than air temperature around shoot tissue. During the freezing treatments, rhizosphere temperatures were $+4^{\circ} \mathrm{C}$ (control), $-1^{\circ} \mathrm{C},-4^{\circ} \mathrm{C},-8^{\circ} \mathrm{C}$ and $-18^{\circ} \mathrm{C}$.

\section{Apical damage index $\left(I_{t}\right)$}

The electrical conductivity was evaluated according to the procedure described by Colombo et al. (1984). After the freezing tests were completed, the apices of six seedlings/ block/temperature were immersed overnight (18 hours) in $100 \mathrm{ml}$ of demineralized water at $+4^{\circ} \mathrm{C}$. The following morning, the Erlenmeyer flasks were shaken vigorously by hand (10 seconds) and the electrical conductivity of this solution $\left(E C_{1}\right)$ was measured immediately using a conductivity meter (model 160; Orion Research, Boston, MA). The samples were then placed in an autoclave for 15 minutes at $121^{\circ} \mathrm{C}$ to destroy the cell membranes and maximize electrolyte leakage. After autoclaving, the solution was left to stabilize overnight (18 hours) at $4^{\circ} \mathrm{C}$. The following morning, the solution was vigorously shaken before its electrical conductivity was remeasured $\left(E C_{2}\right)$. The relative electrical conductivity $(R C)$ was calculated using the following formula:

$$
\text { [1] } R C=\frac{E C_{1}}{E C_{2}} \times 100
$$

Cold hardiness to a given temperature $(t)$ was expressed using an index of injury $\left(I_{t}\right)$ calculated on a percentage basis (Flint et al. 1967):

$$
\text { [2] } I_{t}=\frac{R C_{\text {frozen(t) }}-R C_{\text {control }}}{1-\left(R C_{\text {control }} / 100\right)}
$$

where $I_{t}$ indicates the amount of injury as a function of freeze severity. A high $I_{t}$ signifies a low level of cold tolerance (Flint et al. 1967).

\section{Root water loss (RWL)}

Cold damage to root tissue was evaluated by calculating the percentage of water lost from the root systems (RWL) of six seedlings/block/temperature (Fig. 2.). Following the procedure described by Ritchie (1990) and adapted for two-yearold white spruce seedlings by Coursolle $e t$ al. (2000), RWL was evaluated as the difference in weight of the saturated tissues before and after being sealed in a pressure chamber (model 600, PMS Instrument Co., Corvallis, OR) for 10 minutes at 1.5 $\mathrm{MPa}$, during which time root water was expressed through the cut stem protruding from the chamber.

Initiation of new roots $\left(R_{w} / R_{t}\right)$ and shoot damage $\left(\mathrm{N}_{\mathrm{d}} / \mathrm{N}_{\mathrm{t}}\right)$

Once the artificial freezing tests had been completed, six seedlings/block/temperature were repotted into three-litre plastic pots filled with a moist peat:vermiculite (3:1) mixture and subsequently placed under optimal greenhouse conditions for 21 days (photoperiod $=14$ hours; $\mathrm{T}^{\circ} \mathrm{C}$ day: night $=25^{\circ} \mathrm{C}: 18^{\circ} \mathrm{C}$ $\pm 3^{\circ} \mathrm{C}$ ). High pressure sodium (HPS) lamps (400 W, P.L. 780, P.L. lighting systems) were used to extend the photoperiod to 14 hours/day. Seedlings were watered regularly, but were not fertilized.

Twenty-one days after repotting, the substrate was gently washed from the seedlings' root systems. All fine white roots ( $\geq 1 \mathrm{~cm}$ long) that had developed during the growth test were removed, dried, and weighed. Older, lignified roots, formed prior repotting, were also dried and weighed. The initiation of new roots was quantified, for each growth test, by the ratio of new white root mass $\left(\mathrm{R}_{\mathrm{w}}\right)$ to total seedling root mass $\left(\mathrm{R}_{\mathrm{t}}\right)$, $\left(\mathrm{R}_{\mathrm{w}} / \mathrm{R}_{\mathrm{t}}\right)$.

Dead foliage that had fallen off the branches during the growth test was also collected. At the end of the 21-day period, shoot damage resulting from the freezing treatments was quantified by calculating the ratio of dead needle dry mass $\left(\mathrm{N}_{\mathrm{d}}\right)$ to total needle dry mass $\left(\mathrm{N}_{\mathrm{t}}\right),\left(\mathrm{N}_{\mathrm{d}} / \mathrm{N}_{\mathrm{t}}\right)$.

\section{Statistical analyses}

A strip-strip plot design was used for this experiment (Bernier-Cardou and Bigras 2001). The main plots consisted of the four sampling dates (experimental unit $=60$ seedlings/block), while the subplots were associated with the five artificial freezing temperatures (experimental unit $=12$ seedlings).

Polynomial contrasts were used to characterize the effect of date on bud set.

Correlations between DM/FM and date (expressed in Julian Day), chilling sum, HDD and DHD were computed using the CORR procedure (SAS Institute Inc., Cary, NC).

$\mathrm{DM} / \mathrm{FM}$ was regressed against natural photoperiod length, expressed in hours, by linear regression with the REG procedure (SAS Institute Inc., Cary, NC).

The relationship between DM/FM and HDD was modeled using a hyperbola with the general expression:

$$
\text { [3] } F(x)=\frac{a+b x}{c+x}
$$


where $F(x)$ is DM/FM observed after the accumulation of $x$ HDD, $a$ is the DM/FM value before the accumulation of any HDD, $b$ is the increase in DM/FM from its value at the beginning $(a)$ and its maximum possible value $(a+b)$, and $c$ in the number of HDD when half of the maximum increase in $\mathrm{DM} / \mathrm{FM}(b / 2)$ is reached. This hyperbola was fit to the data using PROC NLIN (SAS Institute Inc., Cary, NC).

Damage assessment variables following artificial freezing treatment were analyzed using PROC MIXED (SAS Institute Inc., Cary, NC.) (Littell et al. 1996, Bernier-Cardou and Bigras 2001). Date, temperature, and their interactions were considered to be fixed effects, whereas the effects of blocks and their interactions were considered to be random. Simple effects were considered significant at a threshold of 5\% and double interactions at a threshold of $1 \%$. If a date $\mathrm{x}$ temperature interaction proved to be significant, an analysis by date was conducted to better characterize the interaction and to clarify the progression of seedling hardening with respect to freezing temperatures (Milliken and Johnson 1984). For each date, an F-test was used to determine if at least one difference existed among the five temperatures. If the test was found to be significant, a Student's t-test was conducted to compare the temperatures two by two (SLICE and PDIFF options of the LSMEANS statement of PROC MIXED) (Littell et al. 1996).

Finally, correlations between DM/FM, chilling sum, HDD, DHD and $\mathrm{I}_{\mathrm{t}}, \mathrm{RWL}, \mathrm{N}_{\mathrm{d}} / \mathrm{N}_{\mathrm{t}}$, and $\mathrm{R}_{\mathrm{w}} / \mathrm{R}_{\mathrm{t}}$ were computed using the CORR procedure, by considering an average value of DM/FM by date and each freezing temperature separately.

\section{Cold tolerance thresholds}

Cold tolerance thresholds were determined from the damage assessment variables $\left(I_{t}, R W L, N_{d} / N_{t}\right.$, and $\left.R_{w} / R_{t}\right)$. A cold tolerance threshold indicates the minimum freezing temperature that a seedling is able to tolerate without sustaining morphophysiological damage (Lamhamedi et al. 2005). Consequently, for a given date, the threshold value was the lowest freezing temperature at which damage not significantly different from the value measured for the control seedlings was observed. The rate of acquisition of cold tolerance can be used to generate the daily progression of cold tolerance thresholds. These rates are calculated from the slope of the mathematical linear model linking the cold tolerance levels on two consecutive sampling dates (Lamhamedi et al. 2005).

\section{Results}

\section{Progression of bud set and apical dry mass ratio}

Bud set exhibited a quadratic progression over time $(P<$ 0.0001 ), with the most rapid bud set occurring at the beginning of the observation period (Fig. 3a).

$\mathrm{DM} / \mathrm{FM}$ increased from $22.5 \%$ on August 1 to $38.9 \%$ on October 28. This increase with time was linear as exhibited by significant strong negative correlation with the natural photoperiod length $(r=-0.92, P<0.0001)$. The linear regression modeling the progression of DM/FM as a function of the photoperiod length was highly significant $(P<0.0001)$ and explained $84.6 \%$ of the variation observed for DM/FM (Fig. 3a).

DM/FM was significantly and positively correlated with chilling sum $(r=0.57, P<0.0001)$, $\operatorname{HDD}(r=0.94, P<0.0001)$, and $\mathrm{DHD}(r=0.72, P<0.0001)$.

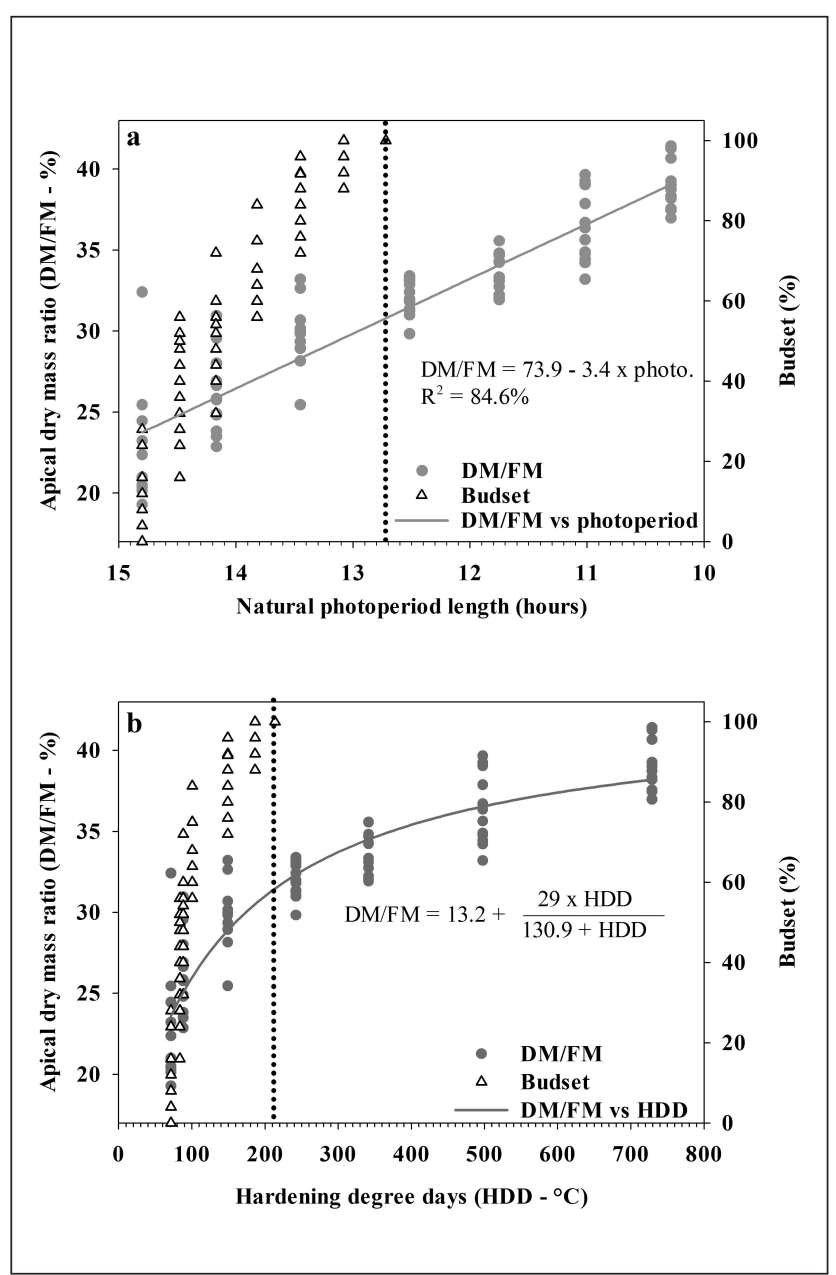

Fig. 3. Progression of apical dry mass ratio (DM/FM) and bud set of two-year-old white spruce seedlings as a function of (a) natural photoperiod length or (b) hardening degree days (HDD). For $\mathrm{DM} / F \mathrm{M}$, each point represents one seedling $(\mathrm{n}=60)$. For bud set, each point represents one container of 25 seedlings $(n=$ 12). The vertical dotted lines on both figures mark the point of $100 \%$ bud set.

Because of its strongest correlation with DM/FM, HDD, based on the minimum daily temperature measured $2 \mathrm{~m}$ above the seedling bed and calculated by summing the degrees below a threshold value equals to $14.5^{\circ} \mathrm{C}$, was used in the hyperbola model to show the relationship between DM/FM and HDD $(P<0.0001)$ (Fig. 3b).

\section{Hardening of seedlings \\ Hardening of shoots}

$\mathrm{I}_{\mathrm{t}}$ was significantly affected by freezing temperature and sampling date $(P<0.0001)$ (Table 1$)$. No significant difference was observed in $\mathrm{I}_{t}$ between the control temperature $\left(+4^{\circ} \mathrm{C}\right)$ and the $-4^{\circ} \mathrm{C}$ freezing temperature (Table 2). On the first sampling date, $\mathrm{I}_{\mathrm{t}}$ of control samples $\left(+4^{\circ} \mathrm{C}\right)$ differed significantly from those exposed to $-8^{\circ} \mathrm{C}$ and colder. On the second and third sampling dates, only seedlings subjected to the $-12^{\circ} \mathrm{C}$ and $-20^{\circ} \mathrm{C}$ treatments had $\mathrm{I}_{t}$ values significantly different from those of the control treatment (Table 2). There were no significant differences among $I_{t}$ values at the last sampling 
Table 1. Observed probabilities for fixed effects $(P>F)$ associated with the analysis of variance of cold damage assessment variables following artificial freezing treatments of white spruce seedlings at five temperatures $\left(+4^{\circ} \mathrm{C},-4^{\circ} \mathrm{C},-8^{\circ} \mathrm{C}\right.$, $-12^{\circ} \mathrm{C}$ and $-20^{\circ} \mathrm{C}$ for shoots and $+4^{\circ} \mathrm{C},-1^{\circ} \mathrm{C},-4^{\circ} \mathrm{C},-8^{\circ} \mathrm{C}$ and $-18^{\circ} \mathrm{C}$ for roots) on four different dates (September 16 and 30 , October 14 and 28, 2002) at the end of their second growing season

\begin{tabular}{lcccccc}
\hline & \multicolumn{2}{c}{ Shoots } & & \multicolumn{2}{c}{ Roots } \\
\cline { 2 - 3 } \cline { 6 - 7 } Source of variation & $\mathbf{I}_{\mathbf{t}}$ & $\mathbf{N}_{\mathbf{d}} / \mathbf{N}_{\mathbf{t}}$ & & & $\mathbf{R W L}$ & $\mathbf{R}_{\mathrm{w}} / \mathbf{R}_{\mathbf{t}}$ \\
\hline Date & $<.0001$ & $<.0001$ & & 0.0015 & $\mathrm{~ns}$ \\
Temperature & $<.0001$ & $<.0001$ & & $<.0001$ & $<.0001$ \\
Date $\times$ Temperature & $<.0001$ & $<.0001$ & & 0.0025 & 0.0003 \\
\hline
\end{tabular}

$\mathrm{I}_{\mathrm{t}}$, apical damage index; $\mathrm{N}_{\mathrm{d}} / \mathrm{N}_{\mathrm{t}}$, ratio of dead needle dry mass $\left(\mathrm{N}_{\mathrm{d}}\right)$ to total needle dry mass $\left(\mathrm{N}_{\mathrm{t}}\right)$ after 21 days of growth; RWL, root water loss; $\mathrm{R}_{\mathrm{w}} / \mathrm{R}_{\mathrm{t}}$, ratio of new white root dry mass $\left(\mathrm{R}_{\mathrm{w}}\right)$ to total root dry mass $\left(\mathrm{R}_{\mathrm{t}}\right)$ after 21 days of growth; ns, non significant.

date only. Similarly, $\mathrm{N}_{\mathrm{d}} / \mathrm{N}_{\mathrm{t}}$ diminished with each successive growth test as seedling hardening intensified (Table 2).

\section{Hardening of roots}

RWL was significantly affected by temperature and sampling date $(P<0.0001)$ (Table 1$)$. For the first two sampling dates, only seedlings subjected to the lowest temperature $\left(-18^{\circ} \mathrm{C}\right)$ exhibited RWL values significantly greater than those of the control temperature $\left(+4^{\circ} \mathrm{C}\right.$ ) (Table 2$)$. By the third sampling date (October 14), there was no longer a significant difference among temperature treatments (Table 2).

$\mathrm{R}_{w} / \mathrm{R}_{\mathrm{t}}$ was also influenced by temperature and sampling date (Table 1). On the first sampling date, $R_{w} / R_{t}$ diminished significantly with temperature, beginning at $-4^{\circ} \mathrm{C}$ (Table 2 ). On the second and third sampling dates, the ratio decreased significantly for temperature of $-8^{\circ} \mathrm{C}$ and below (Table 2). No new white roots were formed following the $-18^{\circ} \mathrm{C}$ freezing treatment, regardless of the degree of hardening.

\section{Correlations between hardening levels and DM/FM, chilling} sum, HDD and DHD

Correlations were estimated by considering an average value of DM/FM by date and each freezing temperature separately (Tables 3 and 4). Correlations between DM/FM, chilling sum, HDD and DHD and shoot cold damage assessment variables $\left(\mathrm{I}_{\mathrm{t}}, \mathrm{N}_{\mathrm{d}} / \mathrm{N}_{\mathrm{t}}\right)$ are reported in Table 3, while correlations with root cold damage assessment variables (RWL and $\mathrm{R}_{w} / \mathrm{R}_{\mathrm{t}}$ ) are reported in Table 4.

$\mathrm{I}_{\mathrm{t}}$ and $\mathrm{N}_{\mathrm{d}} / \mathrm{N}_{\mathrm{t}}$ following freezing treatment at $-8^{\circ} \mathrm{C},-12^{\circ} \mathrm{C}$ and $-20^{\circ} \mathrm{C}$ were significantly and negatively correlated with DM/FM, chilling sum, HDD and DHD (Table 3). The correlation coefficients increased with decreases in temperature. When considering the freezing temperatures $t_{2}\left(-8^{\circ} \mathrm{C}\right)$ or $t_{3}$ $\left(-12^{\circ} \mathrm{C}\right)$, either for $\mathrm{I}_{\mathrm{t}}$ or $\mathrm{N}_{\mathrm{d}} / \mathrm{N}_{\mathrm{t}}$, the strongest correlations were observed with DM/FM and HDD (Table 3). By contrast, when considering the freezing temperature $t_{4}\left(-20^{\circ} \mathrm{C}\right)$ and the variable $I_{t}$, the strongest correlations were observed with chilling sum and DHD.

Increasing DM/FM, chilling sum, $\mathrm{HDD}$ or DHD were also correlated with decreasing damage to the roots (Table 4).
Table 2. Means of cold damage assessment variables of shoots and roots of white spruce seedlings following artificial freezing treatments at five temperatures $\left[t_{0}, t_{1}, t_{2}, t_{3}\right.$ and $\left.t_{4}\right)$ on four different sampling dates (September 16 and 30, October 14 and 28, 2002) at the end of their second growing season ( $n=24$ seedlings; except for $N_{d} / N_{t}$ where $n=12$ )

\begin{tabular}{|c|c|c|c|c|}
\hline & \multicolumn{4}{|c|}{ Sampling dates } \\
\hline & Sept. 16 & Sept. 30 & Oct. 14 & Oct. 28 \\
\hline \multicolumn{5}{|l|}{ Shoots } \\
\hline \multicolumn{5}{|l|}{$I_{t}$} \\
\hline$t_{0}$ & $0^{a}$ & $0^{a}$ & $0^{a}$ & $0^{a}$ \\
\hline$t_{1}$ & $-0.32^{a}$ & $0.17^{a}$ & $-0.08^{a}$ & $-0.05^{a}$ \\
\hline$t_{2}$ & $3.46^{b}$ & $1.07^{a}$ & $1.64^{a b}$ & $-0.05^{a}$ \\
\hline$t_{3}^{2}$ & $7.91^{c}$ & $5.29^{b}$ & $3.29^{b}$ & $-0.10^{a}$ \\
\hline & $11.41^{d}$ & $14.75^{c}$ & $8.47^{c}$ & $0.15^{a}$ \\
\hline \multicolumn{5}{|c|}{$\mathrm{N}_{\mathrm{d}} / \mathrm{N}_{\mathrm{t}}(\%)$} \\
\hline $\mathrm{t}_{0}$ & $18.4^{a}$ & $20.8^{a}$ & $18.4^{a}$ & $10.9^{a}$ \\
\hline$t_{1}$ & $20.7^{a}$ & $19.2^{a}$ & $17.3^{a}$ & $11.0^{a}$ \\
\hline$t_{2}$ & $52.8^{b}$ & $20.5^{a}$ & $16.2^{a}$ & $11.0^{a}$ \\
\hline$t_{3}^{2}$ & $81.2^{c}$ & $36.1^{b}$ & $21.3^{a}$ & $11.2^{a}$ \\
\hline$t_{4}^{3}$ & $100.0^{d}$ & $97.9^{c}$ & $60.6^{b}$ & $21.7^{a}$ \\
\hline \multicolumn{5}{|l|}{ Roots } \\
\hline \multicolumn{5}{|c|}{ RWL (\%) } \\
\hline $\mathrm{t}_{0}$ & $5.8^{a}$ & $4.9^{a}$ & $4.9^{a}$ & $4.2^{a}$ \\
\hline$t_{1}$ & $5.6^{a}$ & $4.9^{a}$ & $5.3^{a}$ & $4.1^{a}$ \\
\hline$t_{2}$ & $7.3^{a}$ & $5.4^{a}$ & $5.6^{a}$ & $4.4^{a}$ \\
\hline$t_{3}$ & $6.3^{a}$ & $5.1^{a}$ & $5.5^{a}$ & $4.7^{a}$ \\
\hline $\mathrm{t}_{4}$ & $10.8^{b}$ & $9.7^{b}$ & $6.8^{a}$ & $5.1^{a}$ \\
\hline \multicolumn{5}{|c|}{$\mathrm{R}_{\mathrm{w}} / \mathrm{R}_{\mathrm{t}}(\%)$} \\
\hline $\mathrm{t}_{0}$ & $3.44^{a}$ & $2.84^{a}$ & $2.18^{a}$ & $2.24^{a}$ \\
\hline $\mathrm{t}_{1}$ & $2.74^{a}$ & $2.35^{a}$ & $1.97^{a}$ & $1.95^{a}$ \\
\hline$t_{2}$ & $0.97^{b}$ & $2.03^{a}$ & $1.84^{a}$ & $1.91^{a}$ \\
\hline$t_{3}^{2}$ & $0.37^{c}$ & $0.89^{b}$ & $0.98^{b}$ & $1.44^{a}$ \\
\hline $\mathrm{t}_{4}$ & $0^{c}$ & $0^{c}$ & $0^{c}$ & $0.07^{b}$ \\
\hline
\end{tabular}

$\mathrm{I}_{\mathrm{t}}$, apical damage index; $\mathrm{N}_{\mathrm{d}} / \mathrm{N}_{\mathrm{t}}$, ratio of dead needle dry mass $\left(\mathrm{N}_{\mathrm{d}}\right)$ to total needle dry mass $\left(\mathrm{N}_{\mathrm{t}}\right)$ after 21 days of growth; RWL, root water loss; $\mathrm{R}_{\mathrm{w}} / \mathrm{R}_{\mathrm{t}}$, ratio of new white root dry mass $\left(\mathrm{R}_{\mathrm{w}}\right)$ to total root dry mass $\left(\mathrm{R}_{\mathrm{t}}\right)$ after 21 days of growth; $\mathrm{t}_{0}=+4^{\circ} \mathrm{C}$ for the shoots and the roots; $\mathrm{t}_{1}=-4^{\circ} \mathrm{C}$ for the shoots and $-1^{\circ} \mathrm{C}$ for the roots; $\mathrm{t}_{2}=-8^{\circ} \mathrm{C}$ for the shoots and $-4^{\circ} \mathrm{C}$ for the roots; $\mathrm{t}_{3}=-12^{\circ} \mathrm{C}$ for the shoots and $-8^{\circ} \mathrm{C}$ for the roots; $\mathrm{t}_{4}=-$ $20^{\circ} \mathrm{C}$ for the shoots and $-18^{\circ} \mathrm{C}$ for the roots.

For a given variable and a given date, two means with a different letter are significantly different

However, correlations with root damage variables were generally less than those for shoot damage variables. It is worth noting that significant negative correlations were also found between RWL and $\mathrm{R}_{\mathrm{w}} / \mathrm{R}_{\mathrm{t}}$ of the control seedlings and $\mathrm{DM} / \mathrm{FM}$ or HDD.

\section{Cold tolerance thresholds and forecasting frost risk}

The significant date $\times$ temperature interaction (Table 1 ) for all cold damage variables $\left(I_{t}, N_{d} / N_{t}, R W L, R_{w} / R_{t}\right)$ illustrates a progressive increase in hardening between September 16 and October 28, 2002. The suggested cold tolerance thresholds (Fig. 4) are conservative and have been established at temperatures that are most likely above those that would result in damage to seedling tissues; the actual threshold being somewhere in the range between the temperature of the suggested threshold value and that of the next-lowest temperature at which seedlings were tested. The rate of acquisition of cold tolerance was derived from the slope of the linear function 
Table 3. Pearson correlation coefficients between shoot cold damage assessment variables observed for two-year-old white spruce seedlings after artificial freezing treatments and apical dry mass ratio (DM/FM), chilling sum, hardening degree days (HDD) and degree hardening day (DHD) measured on the same four sampling dates (16 and 30 September, 14 and 28 October 2002). Correlations were estimated by considering each freezing temperature separately $(n=48)$.

\begin{tabular}{llclcc}
\hline Temperature & $\mathbf{t}_{\mathbf{0}}$ & $\mathbf{t}_{\mathbf{1}}$ & $\mathbf{t}_{\mathbf{2}}$ & $\mathbf{t}_{\mathbf{3}}$ & $\mathbf{t}_{\mathbf{4}}$ \\
\hline $\mathrm{DM} / \mathrm{FM}(\%)$ & & & & & \\
$\mathrm{I}_{\mathrm{t}}$ & $n / a$ & $n s$ & $-0.42^{* *}$ & $-0.65^{* * *}$ & $-0.66^{* * *}$ \\
$\mathrm{~N}_{\mathrm{d}} / \mathrm{N}_{\mathrm{t}}$ & $-0.33^{*}$ & $-0.53^{* * *}$ & $-0.62^{* * *}$ & $-0.77^{* * *}$ & $-0.83^{* * *}$ \\
Chilling sum & & & & & \\
$\mathrm{I}_{\mathrm{t}}$ & $n / a$ & $n s$ & $-0.38^{* *}$ & $-0.59^{* * *}$ & $-0.70^{* * *}$ \\
$\mathrm{~N}_{\mathrm{d}} / \mathrm{N}_{\mathrm{t}}$ & $-0.40^{* *}$ & $-0.54^{* * *}$ & $-0.44^{* *}$ & $-0.56^{* * *}$ & $-0.79^{* * *}$ \\
$\mathrm{HDD}$ & & & & & \\
$\mathrm{I}_{\mathrm{t}}$ & $n / a$ & $n s$ & $-0.43^{* *}$ & $-0.66^{* * *}$ & $-0.67^{* * *}$ \\
$\mathrm{~N}_{\mathrm{d}} / \mathrm{N}_{\mathrm{t}}$ & $-0.35^{*}$ & $-0.54^{* * *}$ & $-0.61^{* * *}$ & $-0.76^{* * *}$ & $-0.83^{* * *}$ \\
$\mathrm{DHD}$ & & & & & \\
$\mathrm{I}_{\mathrm{t}}$ & $n / a$ & $n s$ & $-0.39^{* *}$ & $-0.62^{* * *}$ & $-0.70^{* * *}$ \\
$\mathrm{~N}_{\mathrm{d}} / \mathrm{N}_{\mathrm{t}}$ & $-0.39^{* *}$ & $-0.54^{* * *}$ & $-0.48^{* * *}$ & $-0.62^{* * *}$ & $-0.82^{* * *}$ \\
\hline
\end{tabular}

$\mathrm{DM} / \mathrm{FM}$, apical dry mass ratio; $\mathrm{t}_{0}=+4^{\circ} \mathrm{C} ; \mathrm{t}_{1}=-4^{\circ} \mathrm{C} ; \mathrm{t}_{2}=-8^{\circ} \mathrm{C} ; \mathrm{t}_{3}=-12^{\circ} \mathrm{C} ; \mathrm{t}_{4}=-20^{\circ} \mathrm{C}$. Readers are referred to the Fig. 1. caption for the detail of the calculations of HDD, DHD or chilling sum.

$\mathrm{I}_{\mathrm{t}}$, apical damage index; $\mathrm{N}_{\mathrm{d}} / \mathrm{N}_{\mathrm{t}}$, ratio of dead needle dry mass $\left(\mathrm{N}_{\mathrm{d}}\right)$ to total needle dry mass $\left(\mathrm{N}_{\mathrm{t}}\right)$ after 21 days of growth.

$\mathrm{n} / \mathrm{a}$, not applicable; ns, non significant; ${ }^{*} \mathrm{P}<0.05 ;{ }^{* *} \mathrm{P}<0.01$; ${ }^{* *} \mathrm{P}<0.001$

Table 4. Pearson correlation coefficients between root cold damage assessment variables observed for two-year-old white spruce seedlings after artificial freezing treatments and apical dry mass ratio (DM/FM), chilling sum, hardening degree days (HDD) and degree hardening day (DHD) measured on the same four sampling dates (16 and 30 September, 14 and 28 October 2002). Correlations were estimated by considering each freezing temperature separately $(n=48)$.

\begin{tabular}{llllll}
\hline Temperature & $\mathbf{t}_{\mathbf{0}}$ & $\mathbf{t}_{\mathbf{1}}$ & $\mathbf{t}_{\mathbf{2}}$ & $\mathbf{t}_{\mathbf{3}}$ & $\mathbf{t}_{\mathbf{4}}$ \\
\hline DM/FM (\%) & & & & & \\
RWL & $-0.40^{* *}$ & $-0.32^{*}$ & $-0.40^{* *}$ & $-0.30^{*}$ & $-0.68^{* * *}$ \\
$\mathrm{R}_{\mathrm{w}} / \mathrm{R}_{\mathrm{t}}$ & $-0.33^{*}$ & $n s$ & $n s$ & $0.41^{* *}$ & $0.49^{* * *}$ \\
Chilling sum & & & & & \\
RWL & $-0.35^{*}$ & $-0.36^{*}$ & $-0.35^{*}$ & $n s$ & $-0.58^{* * *}$ \\
$\mathrm{R}_{\mathrm{w}} / \mathrm{R}_{\mathrm{t}}$ & $n s$ & $n s$ & $n s$ & $0.36^{*}$ & $0.60^{* * *}$ \\
HDD & & & & & \\
RWL & $-0.40^{* *}$ & $-0.34^{*}$ & $-0.41^{* *}$ & $-0.31^{*}$ & $-0.67^{* * *}$ \\
$\mathrm{R}_{\mathrm{w}} / \mathrm{R}_{\mathrm{t}}$ & $-0.31^{*}$ & $n s$ & $n s$ & $0.41^{* *}$ & $0.52^{* * *}$ \\
DHD & & & & & \\
RWL & $-0.36^{*}$ & $-0.35^{*}$ & $-0.37^{* *}$ & $n s$ & $-0.62^{* * *}$ \\
$\mathrm{R}_{\mathrm{w}} / \mathrm{R}_{\mathrm{t}}$ & $n s$ & $n s$ & $n s$ & $0.38^{* *}$ & $0.58^{* * *}$ \\
\hline
\end{tabular}

$\mathrm{DM} / \mathrm{FM}$, apical dry mass ratio; $\mathrm{t}_{0}=+4^{\circ} \mathrm{C} ; \mathrm{t}_{1}=-1^{\circ} \mathrm{C} ; \mathrm{t}_{2}=-4^{\circ} \mathrm{C} ; \mathrm{t}_{3}=-8^{\circ} \mathrm{C} ; \mathrm{t}_{4}=-18^{\circ} \mathrm{C}$. Readers are referred to the text for the detail of the calculations of HDD, DHD or chilling sum.

RWL, root water loss; $\mathrm{R}_{w} / \mathrm{R}_{\mathrm{t}}$, ratio of new white root dry mass $\left(\mathrm{R}_{\mathrm{w}}\right)$ to total root dry mass $\left(\mathrm{R}_{\mathrm{t}}\right)$ after 21 days of growth.

ns, non significant; ${ }^{*} \mathrm{P}<0.05 ;{ }^{* *} \mathrm{P}<0.01 ;{ }^{* * *} \mathrm{P}<0.001$

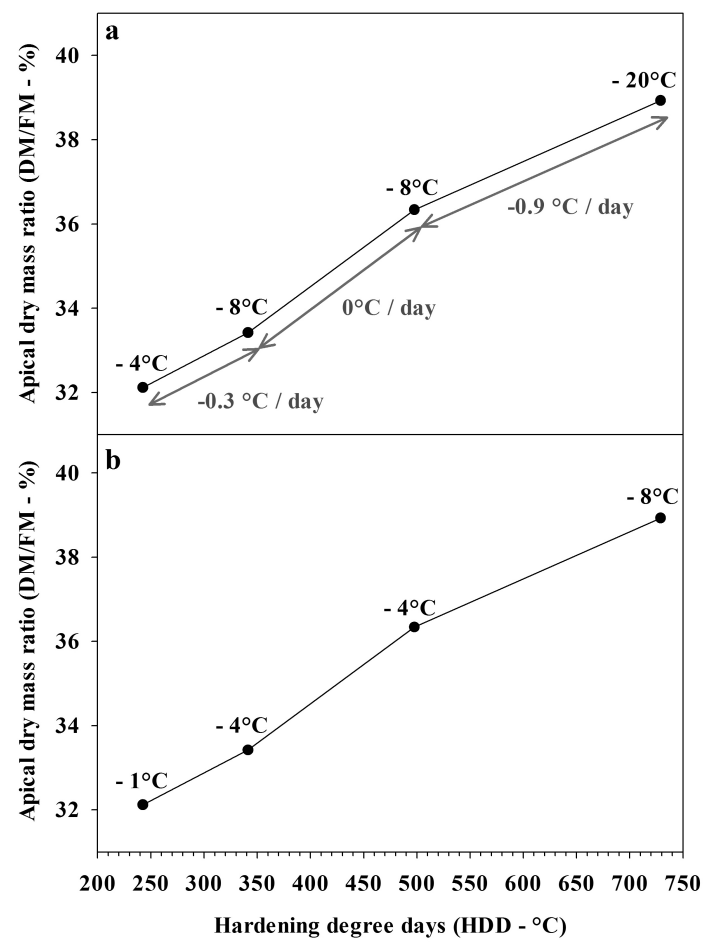

Fig. 4. Progression of cold tolerance thresholds for: a) shoots and b) roots of two-year-old white spruce seedlings. The arrows indicate the rate of acquisition of cold tolerance derived from the slopes $\left({ }^{\circ} \mathrm{C} /\right.$ dayl between cold tolerance thresholds on two consecutive sampling dates. The number of HDD was based on the minimum temperature of the day measured $2 \mathrm{~m}$ above the seedlings and calculated by daily summing the degrees below a threshold value equal to $14.5^{\circ} \mathrm{C}$

between cold tolerance levels on two successive sampling dates (Fig. 4) and can be used to estimate daily cold tolerance levels for shoot and root tissues of two-year-old white spruce seedlings by linear interpolation.

\section{Discussion}

This study was carried out to determine a rapid, non-destructive method of estimating the level of cold hardiness reached by white spruce when a frost event is forecast before the seedlings are fully hardened. This would permit nursery managers to optimize the use of irrigation as a method of protecting seedlings from cold damage. Two variables had been identified as strongly and significantly correlated with seedling cold hardiness: the dry mass ratio [dry mass/fresh mass - DM/FM (\%)] of the uppermost $4 \mathrm{~cm}$ of the terminal shoot and the hardening degree days $\left(\mathrm{HDD}-{ }^{\circ} \mathrm{C}\right)$, based on the minimum daily temperature measured $2 \mathrm{~m}$ above the seedling bed and calculated by summing the degrees below a threshold value of $14.5^{\circ} \mathrm{C}$. These two variables can be used operationally to develop cold tolerance thresholds specific to white spruce seedlings.

In the present study, three variables were used to estimate the thermal time: two are currently being used in forest nurseries (chilling sum and degree hardening days - DHD), and a 
third one is specific to this study (hardening degree days) (Fig. 1). However, nursery managers do not use chilling sum or degree hardening days to estimate seedling cold hardiness levels, but rather to estimate the readiness of bare-root seedling for cold storage. In Québec nurseries, bare-root white spruce seedlings are considered ready for cold storage if the chilling sum has reached a minimum value of 200 hours (Lambany 1994) or, as in Swedish nurseries, when DM/FM has reached a value equal to or above $30 \%$ (Hultén and Lindell 1980). In the present study a chilling sum of 200 hours was reached between the October 14 and 28. By October 21, DM/FM had been above 30\% for at least five weeks. According to our results, a DM/FM of $32 \%$ was associated with a shoot cold tolerance level of $-4^{\circ} \mathrm{C}$ while a chilling sum of 200 hours was associated with a shoot cold tolerance level of $-14^{\circ} \mathrm{C}$. This means that these two threshold values are definitively neither equivalent nor interchangeable. According to Mullin and Parker (1976), bare-root white spruce seedlings are ready for cold storage after a minimum accumulation of 200 degree hardening days (DHD). By October 28, our last sampling date, only $155 \mathrm{DHD}$ had been accumulated. At this time, roots of the containerized seedlings were able to withstand a temperature of $-8^{\circ} \mathrm{C}$ without any damage (Table 2). There is a greater and more rapid decrease in rhizosphere temperature of containerized seedlings compared to that of bare-root seedlings because the container cavities are above the soil surface, surrounded by cold air, and have a small thermal mass due to their limited volume (Colombo et al. 2001). Consequently, DHD are likely accumulated more rapidly for containerized seedlings, permitting a more rapid and deeper hardening, given that root hardening is temperature-dependent (Bigras et al. 2001). This implies that a given DHD value, and its associated level of hardiness, will be reached later in the fall by bare-root seedlings in comparison to containerized stock. With respect to the above-ground portion of the seedlings, differences between thermal properties of the rhizosphere of bare-root vs. containerized seedlings imply that for the same air temperatures, rhizosphere temperatures of the bare-root seedlings will stay warmer than those of the containerized seedlings. The second phase of shoot hardening is temperature-dependent (Bigras et al. 2001), so if bareroot and container seedlings produced in the same nursery are compared at a similar DHD value, the shoots of the containerized seedlings will be more hardened than those of the bare-root seedlings. All this leads us to believe that the threshold value recommended by Mullin and Parker (1976) is conservative when applied to containerized seedlings. Among the three variables used to estimate the thermal time in this study, the hardening degree days (HDD) were the most strongly correlated with shoot and root cold damage assessment variables (Tables 3 and 4). HDD also offers the additional advantage of starting to increase early in the season, so that non-zero threshold values can be associated with distinct cold tolerance thresholds (Fig. 4). HDD, as estimated in the present study, could be easily and effectively used as the basis for a model for predicting cold tolerance levels of shoot and the root tissues of two-year-old white spruce seedlings.

Interestingly, the 30\% threshold recommended by Calmé et al. (1993), or used in Sweden to estimate the capacity of coniferous bare-root seedlings to survive cold storage (Hultén and Lindell 1980), is very close to the values obtained from the relationship between DM/FM and photoperiod, or $\mathrm{DM} / \mathrm{FM}$ and HDD at the completion of bud set (i.e., when photoperiod $=12.72$ hours and $\mathrm{HDD}=214^{\circ} \mathrm{C}$ ). Similarly, Grossnickle (1989) related the variation in the water content of white spruce shoots to phenological changes. Silim and Lavender (1994) also identified the link between hardening and bud set in white spruce seedlings. The increase in $\mathrm{DM} / \mathrm{FM}$ with bud set may result from an increase in dry matter due to tissue lignification following the cessation of height growth (Levitt 1980, Grossnickle 1989). The present study demonstrated that DM/FM continued to increase after bud set. Increased accumulation of dry matter and decreased water content could explain increased DM/FM given that the completion of bud set is followed by a heightening in the degree of hardening (Bigras and D'Aoust 1993, Silim and Lavender 1994, Bigras et al. 2001) which is associated with water loss and the accumulation of starches and sugars (Levitt 1980; Sakai and Larcher 1987). Given that seedlings with a $\mathrm{DM} / \mathrm{FM}$ (\%) above $30 \%$ are considered ready for cold storage (Calmé et al. 1993, Hultén and Lindell 1980), the threshold value of $220^{\circ} \mathrm{C}$ HDD could be used as a rapid and nondestructive criterion for estimating seedling readiness for cold storage and could replace the overly conservative value of 200 hours of chilling sum presently used by nursery managers (Lambany 1994). As DM/FM continues to increase after bud set, it seems appropriate to use this ratio as a basis for a model for predicting cold tolerance levels of shoot and root tissues of two-year-old white spruce seedlings.

With respect to seedling root tissues, significant negative correlations were also found between DM/FM, RWL, and $\mathrm{R}_{\mathrm{w}} / \mathrm{R}_{\mathrm{t}}$ for the control seedlings, indicating that these variables change over time. Ritchie (1990) suggested that optimal chamber pressure and time of exposure might exhibit seasonal fluctuations. This could result in slight differences in the values obtained for the control seedlings since all measurements were done at the same pressure and length of exposure. Similarly, seedling root growth potential, estimated in the present study by $R_{w} / R_{t}$, has been shown to exhibit seasonal fluctuations (McKay and Mason 1991). Consequently, we do not believe that the observed correlations between DM/FM and RWL and $R_{w} / R_{t}$ for the control seedlings question the appropriateness of using DM/FM as an indicator of cold tolerance of white spruce seedling roots. Rather, they illustrate the difficulty of assessing cold damage to roots (Ritchie 1990; Coursolle et al. 2000) and further validate the need to identify a variable that would be quick and easy to measure and from which cold tolerance levels of roots could be estimated.

The rate of acquisition of cold tolerance has been derived from the slope of the linear function between cold tolerance levels on two successive sampling dates (Fig. 4) (Lamhamedi et al. 2005). The obtained values increased with the accumulation of HDD and are similar to the rate of hardening estimated by Greer et al. (2001) for white spruce seedlings exposed to progressively lower temperatures. Because the temperature interval between two successive artificial freezing treatments was at least $4^{\circ} \mathrm{C}$, the rate of cold tolerance acquisition has likely been underestimated (Lamhamedi et al. 2005) since only large changes in hardening level could be detected. This underestimation could explain why the rate equalled zero between the second and the third sampling dates. The estimates of the rate of acquisition of cold tolerance 
could be improved with additional and more closely spaced freezing temperatures. Rates could then be used to estimate daily cold tolerance thresholds.

\section{Conclusion}

When freezing temperatures are forecast, nursery managers need to be able to estimate the level of seedling cold hardiness immediately. They do not have time to conduct a freezing test and need a simple procedure that is based on variables that are quick and easy to measure. The present study validated the appropriateness of DM/FM as an indicator of cold tolerance of the shoot and root tissues of two-year-old white spruce seedlings produced under operational conditions. It also established the appropriateness of using HDD, as estimated in the present study, as the basis for cold tolerance thresholds that would permit cold tolerance levels of shoot and root tissues of two-year-old white spruce seedlings to be predicted. Combining HDD with DM/FM is advantageous because HDD integrate the inter-annual temperature variability while $\mathrm{DM} / \mathrm{FM}$ is linked to the seedlings and integrates the interactions that exist between seed source/provenance and the cultural conditions applied in the nursery (Lamhamedi et al. 2005). DM/FM increases linearly with decreasing photoperiod (Fig 3a); the addition of photoperiod does not seem relevant.

Once developed, the cold tolerance thresholds will permit the nursery managers to estimate the level of seedling cold hardiness almost immediately and to optimize irrigation as a method of protection against autumnal cold damage (Lamhamedi et al. 2005). But before these cold tolerance thresholds can be used, they would have to be developed for each given nursery $\times$ species $\times$ seed source combination by successive freezing tests over a period of three or four years.

\section{Acknowledgements}

This project was carried out in collaboration with Pampev Inc. (Saint-Louis-de-Blandford, Québec), the Ministère des Ressources naturelles et de la Faune (MRNF) du Québec and the Laurentian Forestry Centre (Canadian Forest Service). The authors thank Bertrand Fecteau, Denis Lavallée, Mario Renaud, Claude Fortin, Marie-Claude Martel, MarcAndré Giasson and Marie Coyea for their technical assistance. Financial support to Hank Margolis for this project was provided by the Fonds québécois de la recherche sur la nature et les technologies (FQRNT) (project: 2001-FF79130) and to Dr. Mohammed Lamhamedi by the MRNF (projects: 3071 and 3076).

\section{References}

Bernier-Cardou, M. and F.J. Bigras. 2001. The analysis of Cold Hardiness Experiments. In F.J. Bigras and S.J. Colombo (eds.). Conifer Cold Hardiness. pp. 403-435. Kluwer Academic Publishers, Dordrecht, the Netherlands.

Bigras, F.J. and A.L. D'Aoust. 1993. Influence of photoperiod on shoot and root frost tolerance and bud phenology of white spruce seedlings (Picea glauca). Can. J. For. Res. 23: 219-228.

Bigras, F.J., A. Ryyppö, A. Lindström and E. Stattin. 2001. Cold acclimation and deacclimation of shoots and roots of conifer seedlings. In F.J. Bigras and S.J. Colombo (eds.). Conifer Cold Hardiness. pp. 57-88. Kluwer Academic Publishers, Dordrecht, the Netherlands.
Calmé, S., H.A. Margolis and F.J. Bigras. 1993. Influence of cultural practices on the relationship between frost tolerance and water content of containerized black spruce, white spruce, and jack pine seedlings. Can. J. For. Res. 23: 503-511.

Calmé, S., H.A. Margolis, F.J. Bigras and D. Mailly. 1995. The relationship between water content and frost tolerance in shoots of hardwood seedlings. Can. J. For. Res. 25: 1738-1745.

Carles, S., M.S. Lamhamedi, D.C. Stowe, H.A. Margolis, P.Y. Bernier, L. Veilleux and B. Fecteau. 2008. Frost tolerance of twoyear-old Picea glauca seedlings grown under different irrigation regimes in a forest nursery. Scand. J. For. Res. 23: 137-147.

Colombo, S.J. 1997. Frost hardening spruce container stock for overwintering in Ontario. New Forests. 13: 449-467.

Colombo, S.J., M.I. Menzies and C. O'Reilly. 2001. Influence of nursery cultural practices on cold hardiness of coniferous forest tree seedlings. In F.J. Bigras and S.J. Colombo (eds.). Conifer Cold Hardiness. pp. 223-252. Kluwer Academic Publishers, Dordrecht, the Netherlands.

Colombo, S.J., D.P. Webb and C. Glerum. 1984. Operational monitoring of frost hardiness for guiding the Extended Greenhouse Culture method of hardening spruce container stock. Ontario Ministry of Natural Resources. 16 p.

Coursolle, C., F.J. Bigras and H.A. Margolis. 2000. Assessment of root freezing damage of two-year-old white, black spruce and jack pine seedlings. Scand. J. For. Res. 15: 343-353.

Flint, H.L., B.R. Boyce and D.J. Beattie. 1967. Index of injury a useful expression of freezing injury to plant tissues as determined by the electrolytic method. Can. J. Plant Sci. 47: 229-230.

Greer, D.H., I. Leinonen and T. Repo. 2001. Modelling cold hardiness development and loss in conifers. In F.J. Bigras and S.J. Colombo (eds.). Conifer Cold Hardiness. pp. 437-460. Kluwer Academic Publishers, Dordrecht, the Netherlands.

Grossnickle, S.C. 1989. Shoot phenology and water relations of Picea glauca. Can. J. For. Res. 19: 1287-1290.

Grossnickle, S.C. 2000. Ecophysiology of northern spruce species: the performance of planted seedlings. NRC Research Press, Ottawa, ON.

Hultén, H. and M. Lindell. 1980. TS-halt ett mått på invintring. Avd. för skogsförnyelse, Sveriges Lantbruksuniversitet, Garpenberg, Sweden.

Lambany, G. 1994. La dynamique morphologique et physiologique de plants soumis à un entreposage de longue durée - Mémoire de recherche no114. Ministère des Ressources naturelles. Direction de la recherche forestière.

Lamhamedi, M., M. Renaud and L. Veilleux. 2005. Élaboration des seuils de tolérance au gel des plants d'épinette blanche $(1+0)$ en pépinière forestière selon les régions écologiques du Québec Mémoire de recherche ${ }^{\circ} 147$. Gouvernement du Québec - Ministère des Ressources naturelles - Forêt Québec - Direction de la recherche forestière, Sainte Foy, Qc. 53 p.

Lamhamedi, M.S., G. Lambany, H.A. Margolis, M. Renaud, L. Veilleux and P.Y. Bernier. 2001. Growth, physiology, and leachate losses in Picea glauca seedlings $(1+0)$ grown in air-slit containers under different irrigation regimes. Can. J. For. Res. 31: 1968-1980.

Levitt, J. 1980. Responses of plants to environmental stresses. Vol I. Chilling, freezing, and high temperature stresses, 2nd ed. Academic press, New York London Toronto Sydney San Francisco. $497 \mathrm{p}$.

Littell, R.C., G.A. Milliken, W.W. Stroup and R.D. Wolfinger. 1996. SAS System for Mixed Models. SAS Institute Inc., Cary, NC. $656 \mathrm{p}$.

McKay, H.M. and W.L. Mason. 1991. Physiological indicators of tolerance to cold storage in Sitka spruce and Douglas-fir seedlings. Can. J. For. Res. 21: 890-891.

Margolis, H.A. 1987. Seedling production and reforestation in Québec. Journal of Forestry. 85: 39-43. 
Milliken, G.A. and D.E. Johnson. 1984. Analysis of messy data Volume 1: designed experiments. Van Nostrand Reinhold Company, New York. 473 p.

Mullin, R.E. and J.D. Parker. 1976. Provisional guidelines for fall lifting for frozen overwinter storage of nursery stock. For. Chron. 52: 20-25.

Ritchie, G.A. 1990. A rapid method for detecting cold injury in conifer seedling root systems. Can. J. For. Res. 20: 26-30.

Rose, R. and D.L. Haase. 1996. Irrigation for frost protection in forest nurseries: room for improvement. Western Journal of Applied Forestry. 11: 16-19.

Sakai, A. and W. Larcher. 1987. Frost survival of plants. In Ecological studies. Springer-Verlag, Berlin Heidelberg New York London Paris Tokyo. 321 p.

Silim, S.N. and D.P. Lavender. 1994. Seasonal patterns and environmental regulation of frost hardiness in shoots of seedlings of Thuja plicata, Chamaecyparis nootkatensis, and Picea glauca. Can. J. Bot. 72: 309-316.
Stowe, D.C., M.S. Lamhamedi, S. Carles, B. Fecteau, H.A. Margolis, M. Renaud and P.Y. Bernier. 2010. Managing irrigation to reduce nutrient leaching in containerized white spruce seedling production. New Forests. 40: 185-204.

Veilleux, P., A. Bonneau, J-P. Girard, L. Labrecque, R. Lever, J. Lortie, F-N. Perreault and M. Tourigny. 2012. Guide terrain. Inventaire de qualification des plants résineux cultivés en récipient, document de travail, livraison 2012. Direction générale des pépinières et des stations piscicoles, ministère des Ressources naturelles et de la Faune, Québec.

Zhu, X.B., R.M. Cox, C.-P.A. Bourque and P.A. Arp. 2002. Thaw effect on cold-hardiness parameters in yellow birch. Can. J. Bot. 80: 390-398. 